\section{Scientists talking to the public: is there anyone out there?}

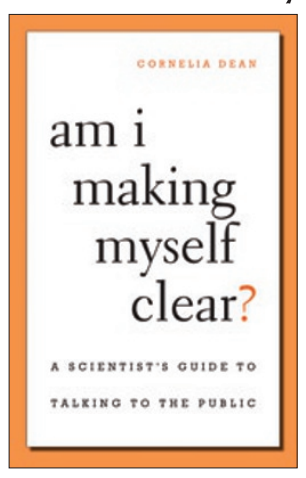

\section{Am I Making Myself Clear? A Scientist's Guide to Talking to the Public}

By Cornelia Dean

Harvard University Press, 2009

288 pages, hardcover, $\$ 19.95$

ISBN 0674036352

Reviewed by Dario L Ringach

In her new book, Am I Making MyselfClear? A Scientist's Guide to Talking to the Public, Cornelia Dean, a journalist and former editor of the popular science section at the New York Times, extends a compelling invitation to researchers to participate more in public life, to explain their work to science journalists, to contribute to national policy debates and to do so not only when their funding is at stake.

Why do scientists need to talk to the public? Because social policies need to be decided on the basis of rational grounds and facts, including issues ranging from climate change, to the goals of the space program, to the protection of endangered species and the use of embryonic stem cells. Neuroscience research using animals, for example, is being increasingly challenged by some who argue it has nothing to contribute to the development of treatments and cures for human disease. If the public and policymakers do not hear the voice of scientists, if they are not presented with the facts, it may only be a matter of time before a large segment of the public will be asking why are we doing (and why they are paying for) such work.

Unfortunately, there are some obstacles between scientists and journalists. Dean correctly notes that the vast majority of researchers do not consider talking to the public as part of their obligation to society. She points out that our current academic system not only fails to promote public discourse, but it actually tends to suppress it. In this context, Donald Kennedy, past editor of Science and President Emeritus of Stanford University, is quoted explaining how researchers expressing an interest in public communication are rapidly treated to a lecture on "the dangers of being Sagan-ized", a reference to the widely believed notion that the noted Cornell astrophysicist was denied a place in the National Academy as a result of his public television series Cosmos. Agreeing with this, Alan Leshner, publisher of Science and former director of the National Institute of Mental Health, is quoted as saying that "public outreach efforts [must be] among the metrics used to decide promotion and tenure".

The author is in the department of Neurobiology, University of

California Los Angeles, Los Angeles, California, USA.

e-mail: dario@ucla.edu

Another hurdle to communication that is noted by Dean is one of perception; scientists tend to view journalists as superficial, sensationalist and focused on controversy, whereas journalists view researchers as boring, users of unintelligible jargon, caveating things to death and being unable to identify central points. But the single major issue that appears to drive scientists away from the media is the need for journalistic balance, which leads to many researchers being pitted in public against some 'crank' that will provide the opposing view, resulting in what some view as an 'overweighting of dissent'. The author concedes this problem has no easy solution, representing the major issue in her coverage of science and engineering.

A number of chapters provide an excellent practical guide to interacting with the media. This includes tips about how to tell your story, the importance of sound bites, the effective use of your time in radio and TV, writing letters to the editor, Op-Ed pieces and books, writing your own blog, standing on the witness stand, and engaging in policy making. These practical recommendations are all excellent, but may be difficult to follow for the newcomer. The key, Dean says, is to prepare ahead of time. Know your most important points and be ready to deliver them in seconds. When it comes to discussing the actual science, make sure you know your audience, avoid jargon and practice every day by explaining your work to your family, neighbors and whoever is sitting next to you on the plane.

Many scientific leaders and politicians are quoted throughout the book in memorable passages encouraging scientists to participate more in public life. In a particularly compelling excerpt from a meeting of the American Association for the Advancement of Science (AAAS), Congressman Sherwood Boehlert tells his audience that "Scientists should participate actively, even avidly, in policy debates. Indeed, both as educated citizens and as professionals with relevant knowledge, scientists ought to feel obligated to contribute to policy making in their communities, in the nation and even in the wider world". Addressing another meeting of AAAS, his congressional colleague John Porter brings an entire hall into wild applause by offering the view that "Scientists are by every measure the most respected people in America. They are listened to. But if the public and policymakers never hear your voices, never see... science, never understand its methods, the chance of its being high on the list of national priorities will be very low. [...] You can sit on your fingers or you can go outside your comfort zone and get into the game and make a difference for science. Neither we, nor AAAS, nor any other group can do it all for you. Science needs you. Your country needs you. America needs you... fighting for science!".

I couldn't agree more. It is time for all of us to have a more active role in society and provide our input to public policy; we must go beyond the publication of scientific articles. I admit my own recent incursion into the media was not driven by any of the above considerations, but from threats by animal rights extremists. I don't recommend you take the same road. Instead, read this powerful book and you will be easily convinced that it is your obligation to devote time outside the laboratory to communicating the wonderful work you are doing, your excitement, its importance and how the public stands to benefit from it.

Is there anyone out there ready to talk about science? I certainly am. 